\title{
Injury Profile and Risk Factors in a Young High Competitive Population of Judo Athletes
}

\begin{abstract}
Marcos António Fernandes de Carvalho*, Miguel Alexandre do Nascimento, Vítor Hugo Teixeira Pinheiro, Ugo Alves Fontoura, André Pereira Pinto, Sandra Filipa Nunes dos Santos, João Pedro Moreira de Oliveira and Fernando Manuel Pereira Fonseca
\end{abstract}

Orthopaedics Department of Coimbra's Hospital and Universitary Centre, Portugal

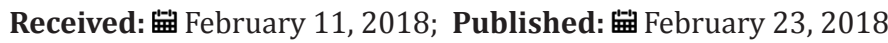

*Corresponding author: Marcos António Fernandes de Carvalho, Orthopaedics Department of Coimbra’s Hospital, Universitary Centre, Portugal.

\section{Abstract}

Background: High competitive level judo practice from a very young age, may lead to an increasing risk of injury. The aim of this study is to identify injury risk factors in a young high-level judo population to develop future specific strategies for injury prevention.

Methods: An individual questionnaire was applied by physicians to cadet and junior athletes that competed in international judo tournaments in 2014. Statistical inferential analysis was performed to identify the major injury risk factors and injury patterns in these ages.

Results: 212 athletes from 13 different countries (53\% portuguese) answered the questionnaire. Male predominance was found, and a mean age of $16,8 \pm 1,5$ years with $9,7 \pm 3$, 1years of judo practice. We found 347 injuries, with $83 \%$ of the athletes reporting at least one injury. The majority of injuries occurred to the limbs (85\%) during training period (71\%), in the throwing phase (87,6\%), as a consequence of direct contact (72\%) and with articular involvement (62\%). Sprain was the most common type (36\%) and shoulder the most specific segment affected (25\%) with an occurrence twice as high during defense movements $[\mathrm{p}=0,018]$. Injury occurrence was associated with training load $(p=0,001)$, whilst the number of injuries with the age $[p=0,005]$, need to lose weight $(p=0,007)$ and training $\operatorname{load}(0,001)$.

Conclusions: Increasing age, need to lose weight and training load were identified as injury risk factors for these ages. We also verified that shoulder injuries are significantly more frequent during defense movements, being these ones that led to more severe injuries

Keywords: Judo; Sports injury; Trauma; Young athletes; Martial arts

\section{Introduction}

Judo is a combat sport often related to injuries since it is associated with a significant direct contact [1,2]. Although injuries occur, judo is considered one of the most safest sports activity due to low injury rates [3], being in fact considered by UNESCO as the best sport for children and young people between 4-21 years old. Nowadays, because of the early competitive practice, specialization and intensive training load among young athletes, we are seeing different injury patterns and severity in these ages $[2,4,5]$. The potential vulnerability of these athletes due to the physical and physiological processes of growth exposed to high levels of activity, is a reason of concern $[4,6]$ which must stimulate the development of this specific knowledge, in particular the analysis of risk factors in order to provide preventive injury programs and educative measures. With this study, we intend to reinforce the epidemiologic knowledge specific to judo in these particular ages, and, by knowing the risk factors and more common injury features and patterns, use them to help us developing the strategies to control and prevent injuries.

\section{Methods}

This was a retrospective cohort study, in which an individual questionnaire was applied to cadet and junior athletes that participate in international competitions in 2014, in Portugal (Cadet European Judo Cup and Junior European Judo Cup, both in Coimbra city). The questionnaire was written in 4 languages 
(portuguese, english, french and Spanish) and it was designed and applied by a group of physicians, focusing on the athlete's intrinsic characteristics, training method and practice level, and, when it exists, sports injury and its treatment. We defined "mild injury" - without any stop of the activity; "moderate injury"-stop for one training session or competition; "severe injury"-stop for more than one training session or competition [7-9]. The study was approved by the Ethics Comitee of the Faculty of Medicine of the University of Coimbra, and all of the athletes included in this study had to sign the informed consent form. Statistical analysis was performed using the IBM SPSS Statistics 21.0 program $(\mathrm{p}<0.05)$.

\section{Results}

\section{Demographic data}

Some of the preliminary descriptive epidemiological data were published previously in an early phase of the study (Table1 \& 2) [10]. Based on the information obtained from the questionnaires, we analyzed the answers of 212 young high competitive judo athletes, from 13 different countries (52\% Portuguese). Of these, 118 were cadet and 94 junior with a mean age of $16.8 \pm 1.5$ years and male predominance $(68.4 \%)$. The more common weight categories were $-60,-66 \mathrm{e}-73 \mathrm{Kg}$ in male gender and $-57,-63$ and $-70 \mathrm{Kg}$ in female gender. We found that 205 athletes compete in categories with weight limit and that 127 (62\%) have a real weight higher than that of their category. Most of the athletes were black belt (55.6\%) and assume a right-handed dominance grip position (73.1\%) while performing judo techniques. We verified that athletes with higher rank were the ones who did more judo trainings sessions per week (Rho=0.254, p<0.001), and hours per day [Rho=0.313, p<0.001] and per week (Rho=0.338, $\mathrm{p}<0.001)$. The average number of years of judo practice was $9.7 \pm 3,1$ (1-16), the number of judo training sessions per week $5.5 \pm 1.9(2-11)$ and hours per day $2.57 \pm 0.9$ (1-6). All athletes reported having warm up sessions prior to judo training, averaging $23.3 \mathrm{~min} \pm 8.8$ [10-60], while $12.7 \%$ answered that they do not usually stretch after activity. Around $65 \%$ of the athletes do gym sessions and strength workouts averaging 2.83 sessions per week. Out of these, $24.1 \%$ perform 4 or more gym sessions per week. We found a statistically significant correlation between the age of the athlete and hours of training per day $(\mathrm{Rho}=0.244, \mathrm{p}<0.001)$ and per week $(\mathrm{Rho}=0.280, \mathrm{p}<0.001)$. We also verified that the athletes who need to lose weight to compete, were the ones who had more judo trainings per week, judo training hours per day and per week and a higher number of gym sessions/strength workout per week (Table 3). Regarding athletes that do gym sessions, we found a statistically significant correlation with age, need to lose weight and judo training load [number of trainings per week, training hours per day and per week]. Comparing portuguese athletes with foreigners regarding the frequency of gym sessions, we found that foreigner athletes do 3.9 times more this type of workout than the portuguese ( $\mathrm{x} 2=19.578, \mathrm{p}<0.001 ; 0 \mathrm{R}=3.861$ [IC95\%: 2.088-7.142]) and that the judo training sessions are on average 14 minutes longer than the portuguese ones [ $p=0.038]$.
Table 1: Demographic Data: athlete intrinsic characteristics, training method and practice level

\begin{tabular}{|c|c|}
\hline \multicolumn{2}{|c|}{ Variable } \\
\hline Age in years, mean (sd) & $16.8( \pm 1.5)$ \\
\hline Gender (M), n (\%) & $145(68.4 \%)$ \\
\hline \multicolumn{2}{|c|}{ Nationality, n (\%) } \\
\hline Portuguese & $112(52.8 \%)$ \\
\hline Non-portuguese & $100(47.2 \%)$ \\
\hline \multicolumn{2}{|c|}{ Age Category, n (\%) } \\
\hline Cadets & $118(55.7 \%)$ \\
\hline Juniors & $94(44.3 \%)$ \\
\hline Years of judo practice, mean (sd) & $9.73( \pm 3.114)$ \\
\hline $\begin{array}{l}\text { Number of trainings/week, mean } \\
\text { (sd) }\end{array}$ & $5.53( \pm 1.917)$ \\
\hline $\begin{array}{l}\text { Time of warm up in minutes, mean } \\
\text { (sd) }\end{array}$ & $23.3( \pm 8.8)$ \\
\hline Stretching after train, n (\%) & $185(87.3 \%)$ \\
\hline Strength/Gym workout, n (\%) & $137(64.6 \%)$ \\
\hline
\end{tabular}

\section{M: male. sd: standard deviation}

Table 2: Frequency, type, distribution and severity of sports injuries in high-competitive level judoka

\begin{tabular}{|c|c|}
\hline \multicolumn{2}{|c|}{ Variable } \\
\hline Athletes with injury, $\mathrm{n}(\%)$ & $176(83 \%)$ \\
\hline Injury/athlete, mean (sd) & $1.64( \pm 1.36)$ \\
\hline \multicolumn{2}{|c|}{ Phase of the fight, n (\%) } \\
\hline Standing & $304(87.6 \%)$ \\
\hline Ground & $43(12.4 \%)$ \\
\hline \multicolumn{2}{|c|}{ Period of practice, n (\%) } \\
\hline Training & $247(71.2 \%)$ \\
\hline Competition & $100(28.8 \%)$ \\
\hline \multicolumn{2}{|c|}{ Action, n (\%) } \\
\hline Attack & $159(45.8 \%)$ \\
\hline Defense & $160(46.1 \%)$ \\
\hline Other & $28(8.1 \%)$ \\
\hline \multicolumn{2}{|c|}{ Anatomical region, $\mathbf{n}(\%)$} \\
\hline Upper Limb & $139(40.1 \%)$ \\
\hline Lower Limb & $155(44.7 \%)$ \\
\hline Axis & $39(11.2 \%)$ \\
\hline Head & $14(4.0 \%)$ \\
\hline \multicolumn{2}{|c|}{ Type of injury, n (\%) } \\
\hline Sprain & $126(36.3 \%)$ \\
\hline Muscular Rupture & $60(17.3 \%)$ \\
\hline Contusion & $56(16.1 \%)$ \\
\hline Fracture & $44(12.7 \%)$ \\
\hline Dislocation & $44(12.7 \%)$ \\
\hline Tendinopathy & $17(4.9 \%)$ \\
\hline Time-loss injury, n (\%) & $280(80.7 \%)$ \\
\hline
\end{tabular}

sd: standard deviation 
Table 3: Statistically significant correlation with the athletes who need to lose weight

\begin{tabular}{|c|c|c|c|}
\hline & $\begin{array}{c}\text { Need to lose } \\
\text { weight }\end{array}$ & p- value* & Rho \\
\hline Age & + & 0.003 & 0.208 \\
\hline Graduation & + & 0.001 & 0.225 \\
\hline $\begin{array}{c}\text { Years of judo } \\
\text { practice }\end{array}$ & + & $<0.001$ & 0.296 \\
\hline Trainings/week & + & 0.001 & 0.222 \\
\hline $\begin{array}{c}\text { Training hours/ } \\
\text { day }\end{array}$ & + & 0.003 & 0.205 \\
\hline $\begin{array}{c}\text { Training hours/ } \\
\text { week }\end{array}$ & + & $<0.001$ & 0.265 \\
\hline $\begin{array}{c}\text { Strength/Gym } \\
\text { workout }\end{array}$ & + & 0.011 & 0.174 \\
\hline *Spearman's correlation & & \\
\hline
\end{tabular}

\section{*Spearman's correlation}

\section{Frequency of injuries}

We found 347 injuries in $83 \%$ of the athletes, while $17 \%$ reported no injuries due to judo practice. The average number of injuries per athlete was $1.64 \pm 1.36$ (Table 2). We verified a statistically significant correlation between the presence of injury and the number of judo trainings per week $[p=0.005]$ and of judo training weekly hours [ $\mathrm{p}=0.014]$. Regarding the number of injuries, this was statistically significant correlated with age, need to lose weight, number of trainings per week and daily and weekly judo training hours (Table 4). We found no statistically correlation between the occurrence of injury and rank, gender, grip dominance, warm up, stretching, gym sessions or years of practice. We have noticed a tendency for injuries in those who do gym sessions but with no statistical significance. We also did not find any statistically significant correlation between the weight category and the number of injuries, frequence by specific anatomical segment and type of injury or its severity. We observed that the presence of injury was related with the age category $(x 2=8.593, p=0.003)$ with a probability of injury 3.34 times higher in junior athletes when compared with cadets (OR=3,344 [IC95\%: 1,445-7,743]).

Table 4: Statistically significant correlation with the number of injuries.

\begin{tabular}{|c|c|c|c|}
\hline & Injury & p-value* & Rho \\
\hline Age & + & 0.005 & 0.194 \\
\hline Need to lose weight & + & 0.007 & 0.185 \\
\hline Trainings/week & + & 0.001 & 0.237 \\
\hline Training hours/day & + & 0.044 & 0.13 \\
\hline Training hours/week & + & 0.002 & 0.218 \\
\hline
\end{tabular}

*Spearman's correlation

\section{Action and phase of combat}

Most of the injuries (71.2\%) occurred during training sessions (62\% in the pre-competitive phase] [p<0.001 [IC95\%: 0.661$0.759])$ and throwing phase (87.6\%) (p<0.001, [IC95\%: $0.837-$ $0.909])$. The occurrence of injury was similar for both defense (45.8\%) and attack (46.1\%) movements, and 8,1\% of the injuries occurred without any interference of the opponent. However, we observed that the occurrence of shoulder injuries was 1.8 times higher during defense movements $(x 2=5.629, \mathrm{p}=0.018$; $\mathrm{OR}=1.838$ IC95\%: 1.108-3.050). We verified that of all injuries that occurred during groundwork phase, most (55.8\%) occurred during a defense movement of the athlete. We also found that the upper limb injuries were more frequent during groundwork phase $(55,8 \%)$ while those in the lower limbs were during standing phase $(46,7 \%)$ (Table 5). Even tough we found groundwork injuries more common during trainings regarding its absolute number, these injuries were 2.4 times higher in proportion during competition ( $\mathrm{x} 2=7.490$, $\mathrm{p}<0.006 ; 0 R=2.435$ [IC95\%: 1.269-4.670]).

Table 5: Statistically significant differences between anatomical region, phase of combat, injury type, injury mechanism and injury severity.

\begin{tabular}{|c|c|c|c|c|c|c|c|}
\hline & & Upper Limb & Lower Limb & Axial Skeleton & Head & p- value & OR \\
\hline \multirow{2}{*}{ Phase of combat } & Ground & + & & & & $0,024^{*}$ & 2,074 \\
\hline & Standing & & + & & & $0,042^{*}$ & 2,023 \\
\hline \multirow{4}{*}{$\begin{array}{l}\text { Mechanism of } \\
\text { injury }\end{array}$} & \multirow{2}{*}{ Direct contact } & + & & & & $0,006^{*}$ & 2,011 \\
\hline & & & & & + & $0,017 ¥$ & - \\
\hline & $\begin{array}{l}\text { Repeated } \\
\text { motions }\end{array}$ & & + & & & $0,003^{*}$ & 2,574 \\
\hline & Overload & & & + & & $<0,001^{*}$ & 6,439 \\
\hline \multirow{5}{*}{ Type of injury } & Dislocation & + & & & & $<0,001^{*}$ & 15,834 \\
\hline & Tendinopathy & + & & & & $0,002^{*}$ & 5,262 \\
\hline & Muscular injury & & & + & & $<0,001^{*}$ & 8,047 \\
\hline & Contusion & & & & + & $<0,001 ¥$ & 23,467 \\
\hline & Sprain & & + & & & $<0,001^{*}$ & 5,323 \\
\hline \multirow{2}{*}{ Severity } & High & + & & & & $0,049 \beta$ & - \\
\hline & Low & & & & + & $0,05 \beta$ & - \\
\hline
\end{tabular}

** Chi-square; $¥$ Fisher’s Test; $\beta$ Mann-Whitney’s Test 


\section{Injury location}

Regarding injury location, we found a statistically significant higher number of limb injuries [84,8\%], with $40,1 \%$ in the upper limb and $44,7 \%$ in the lower limb. Out of the rest of injuries reported, $11,2 \%$ occur in the axial skeleton and $4 \%$ in the head (Table 2). Analyzing all injuries by specific anatomical segment we verified that shoulder was the most commonly involved $[n=87$, $25.1 \%$ ] followed by the knee $(n=68,19.6 \%)$, ankle $(n=37,10.7 \%)$ and spine $(n=31,8.9 \%)$. About half of the injuries occurred on the right side of the body, $40 \%$ on the left one and $10 \%$ on the median region. We verified with statistically significant difference that most of the injuries had an articular involvement (61.7\%], $[\mathrm{p}<0.001$, [IC95\%: 0.563-0.668]).

\section{Mechanism and types of injury}

The most common mechanism of injury identified was direct contact $[n=249,71.8 \%]$, followed by dynamic overload $(n=50$, $14.4 \%)$ and cyclic overuse $(n=48,13.8 \%)$. On the other side, the most common types of injury identified were sprain [36.3\%], muscular rupture $(17.3 \%)$ and contusion [16.1\%] (Table 2). Fracture and dislocation occurred with the same frequency $(12.7 \%)$ and were the ones that had with higher injury severity. Tendinopathy was found in $4.9 \%$ of the cases. Regarding the type of injuries, we found with statistical significance, that dislocation and tendinopathy were more common in the upper limb, sprain in the lower limb, muscular rupture in the axial skeleton and contusion in the head (Table 5). We also verified that the probability of muscular rupture occurrence was 2 times higher than any of the other types of injury during competition $(\mathrm{x} 2=5.838, \mathrm{p}=0.016$; OR $=2.020$ [IC95\%: 1.134-3.597]). Regarding the mechanism of injury, we found, with statistically significant difference, that the occurrence of contusion was 2.4 times more common than any of the other types of injury during training $[\mathrm{x} 2=5.289, \mathrm{p}=0.021 ; 0 \mathrm{R}=2.376$ (IC95\%: 1.117 5.055)]. We also observed with statistically significant differences that upper limb injuries are more frequent as consequence of direct contact and that those of the axis and lower limb as consequence of dynamic overload (Table 5). We noticed that the mechanism of injury was statistically correlated with the type of injury $(x 2=139,283, p<0,001)$. We verified that muscular rupture was related with dynamic overload, tendinopathy with cyclic overuse, dislocation, fracture, contusion and sprain with direct contact.

\section{Injury severity}

Regarding the impact and severity of the injuries, we verified that $81 \%$ resulted in cessation of the activity. We also noticed with statistically significant difference, a higher proportion of severe injuries during defense movements and of mild injuries on solo movements (no movement/action from the opponent] [H1 $=27.109, p=0.014$ ) (Table 6). In $18 \%$ of the injuries no treatment was needed, while $72 \%$ needed some kind of treatment. About $72 \%$ of the treated injuries required elastic contension, functional bandage or immobilization. We also noticed that $56.2 \%$ of the injuries required physiotherapy and $6.6 \%$ required surgery mainly because of knee pathology (52.2\%)-meniscal tear or anterior cruciate ligament rupture. We did not find any statistically significant correlation between injury severity and its occurrence during training or competition, phase of combat, sports season, mechanism of injury or rank. The most severe injuries were joint dislocation and bone fracture and the less severe was muscular rupture (Table 6). We found that the most severe ones were statistically correlated with the number of years of judo practice of the athletes, and we also verified that athletes that perform more judo trainings per week, tend to have more severe injuries, but without statistical significance $(r=0.098, p=0.0690)$. Regarding the severity of the injury, this was found to be correlated with the type of treatment [ $p=0.007]$, with some of the most severe ones leading to surgical procedures [ $\mathrm{p}=0.045]$ and mild injuries to no procedure at all [ $\mathrm{p}=0.003]$. Analyzing injury severity between portuguese and foreign athletes we found no differences between both groups. Regarding the anatomical segment, we verified that the most severe injuries occur in the upper limb and the less severe in the head (Table 5).

Table 6: Statistically significant differences between injury severity, action, injury type and years of judo practice.

\begin{tabular}{|c|c|c|c|c|}
\hline & & Mild & Severe & p- value \\
\hline \multirow{2}{*}{ Action } & Defense & & + & $0,014^{*}$ \\
\hline \multirow{3}{*}{ Type of Injury } & Dislocation & & + & $0,002^{*}$ \\
\cline { 2 - 5 } & Fracture & & + & $0,008^{*}$ \\
\cline { 2 - 5 } & Muscular injury & + & & $0,04^{*}$ \\
\hline Years of judo practice & & & + & $0,003 \beta$ \\
\hline
\end{tabular}

* Kruskal-Wallis; $\beta$ Pearson's correlation

\section{Discussion}

\section{Demographic data, injury incidence patterns and risk factors}

Based on the results collected in our study, we obtained a diverse sample of athletes from different european countries, with a normal distribution regarding age category and nationality [portuguesese versus foreigners], with a predominance for central weight categories similar to the european trend. Considering the need for high technical requisits, specialization and load training intensity in such a young age, these athletes are more likely to develop injuries in their sports activity [2,4,5,11].With respect to the frequency of injuries, we verified that $83 \%$ of the athletes had at least one injury, a number that seems clearly underestimated: 
for example, we didn't find any ear injuries, skin scratches or epistaxis reported in our study, and we noticed a low number of small articular injuries although they are common in judo practice $[3,12-15]$. The main reason for that is probably related with the socio-psychological profile of judo formers, having higher pain thresholds in relation with the high training intensity. In addition, this also happens due to the demanding competitive calendar and athletes' will of the athletes to pursue their objectives, which makes them train in suboptimal conditions, sometimes hiding injuries, without medical support, reducing quality, intensity and training performance, ultimately leading to chronic injuries or re-injuries [16-19].

We verified that $72 \%$ of all injuries occur during training period, an outcome that is also described in the literature $[16,20]$. This is possibly related to poor training strategy programs with excessive intensity and training load in young ages, which predisposes to a high musculoskeletal fragility $[13,21,22]$. Another reason for this fact is that many athletes undergo strenuous strength workout programs while training hard before competition, all the while maintaining hydric and caloric restriction diets for several days [12,23-27]. This attitude might lead to situations of severe dehydration fluid and electrolyte imbalance which can potentially influence both the physical and psychological performance of the athletes [12,23$25,28-30]$. It is also important to highlight the weight differences between partners during practices [8], which become even more important in the pre-competitive period, during which most of the athletes are already on a diet at these ages. Because of this, it is important to evaluate some risk/benefits for the athletes, when considering the dynamic balance of upgrading skills by fighting with a heavier and more experienced partner and the potential risk of injury because of it before a competition.

Similar to other studies, we found that most of the injuries (74\%) occurred during the throwing phase [31]. This is mainly explained because most of the action during a fight occurs in the standing phase, with associated explosive attacking throws and defense resisting movements counteracting the action [32-34]. verified that a greater injury severity was related to defense movements, which is consistent with the literature [31]. We also found that the occurrence of groundwork injuries was 2.4 times higher in competition than in training, which is probably related with higher fight intensity in this phase of combat during competition [31].

In line with the literature, we observed a total of $85 \%$ of limb injuries [13,35], $72 \%$ of the injuries due to a direct contact mechanism [35-37] and that $62 \%$ of all injuries were articular. This articular involvement is mainly explained by the direct contact mechanism but also because most of the action occurs by working in closed kinetic chains, which, because of the strong musculoskeletal structure of the athletes, causes movement fulcrums such as the joints to become more prone to injury $[13,16,21,35,38]$.Similar to other studies, shoulder was the anatomical segment most commonly affected [19,39] and we observed that its shoulder injury occurrence was 1.8 times higher during defense movements, mainly caused by the resistance of the defender in an attempt not to fall on his back [32-34] .

In our study we verified an $81 \%$ of time-loss injuries, result that, as previously stated, seems clearly related to an underestimation of mild injuries by the athletes, that remember more accurately severe injuries, like dislocation or fracture, because of the obvious repercussion in their sports activity and overall daily activity [40]. Despite this limitation in data quality, we can assume that the information collected is very accurate for severe injuries related to judo practice in young athletes. In $72 \%$ of the cases, athletes used some kind of elastic or functional bandaging or immobilization, usual practice in judo high level athletes, that do it often in a daily basis practice [41].

\section{Limitations}

This study provide us information based in a retrospective analysis of the past injuries of the athletes. Thus, the quality and objective description of the injuries by the athletes, and their treatment, was not the most accurate. The young age of our sample, as well as the subjective impact and significance of the injury reported are athlete-dependent and also contribute to a higher reporting of severe injuries, gives the idea of a larger number of time-loss-injuries while many mild injuries are underestimated or not even reported at all. At the same time, this allows us a very precise and objective description of the most severe injuries of the athletes.

\section{Conclusion}

Judo is commonly associated with injuries, risk that based in our study is greater in athletes that need to lose weight and who are exposed to a more frequent and intensive training loads. In fact, in our high competitive population cohort, we found that $83 \%$ of the athletes reported at least one injury, most of them in the limbs, during the training period, in the standing phase of the combat, as a consequence of direct contact and leading to time-loss injuries. Shoulder was found to be the most common specific anatomical segment injured and its involvement was also significantly higher when associated with defense movements. We observed that lower limb injuries were more common during throwing phase and upper limb injuries during groundwork phase. The most common type of injury was sprain, with the most severe injuries being associated with defense movements. Most of the injuries required some kind of functional bandage/elastic taping and surgery was performed in $7 \%$ of all cases mainly due to meniscal tears and ACL rupture, leading to arthroscopic partial meniscectomy and/or ACL reconstructions. As a final consideration, we emphasize that this study provides and reinforces present epidemiologic data and knowledge regarding judo injuries in such a young high competitive level population. Based in our results and better knowledge of risk 
factors and common injury features and patterns, we will now use them to develop strategies to control and prevent injuries to this particularly young population.

\section{What are the new findings?}

I. This study identifies the epidemiological injury profile of a young high competitive-level population of judo athletes.

II. Age, need to lose weight and training load intensity were identified as risk factors for injury in young judo athletes

III. Injuries occur predominantly in the limbs, as consequence of direct contact mechanism and associated with articular involvement.

IV. Occurrence of injury is more common during training period and in the standing phase

V. Shoulder injuries are the most frequent and they are 2 times more common during the defense movements.

VI. Defense movements are the ones that lead to more severe injuries.

\subsection{How might it impact clinical practice in the near future?}

I. By knowing the risk factors and most common features and patterns of injury in such a young and high competitive judo population, it is possible to alert and educate athletes, coaches and other sports-related personnel, in order to make judo practice even safer.

II. Providing the most recent injury epidemiological data in this particular population, can encourage the development of strategies to control and prevent injuries by the healthcare practitioners.

\section{References}

1. Junge A, Engebretsen L, Mountjoy ML, Alonso JM, Renström PA, et al. (2009) Sports injuries during the Summer Olympic Games 2008. Am J Sports Med 37(11): 2165-2172.

2. Demorest RA, Koutures C, Fitness Cosma (2016) Youth Participation and Injury Risk in Martial Arts. Pediatrics 138(6): e20163022.

3. Jung M (2017) Prospective Injury Statistics During High-Level Judo Competition: An Ijf-Eju Collaboration. British Journal of Sports Medicine 51(4): 338

4. Post EG, Trigsted SM, Riekena JW, Hetzel S, McGuine TA, et al. (2017) The Association of Sport Specialization and Training Volume With Injury History in Youth Athletes. Am J Sports Med 45(6): 1405-1412.

5. Koshida S, Ishii T, Matsuda T, Hashimoto T (2017) Biomechanics of judo backward breakfall for different throwing techniques in novice judokas. Eur J Sport Sci 17(4): 417-424

6. DeLee JC, Drez DJ, Miller M (2009) DeLee \& Drez's Orthopaedic Sports Medicine - Principles and Practicies: Expert Consult. ( $3^{\text {rd }}$ edn), Saunders, Elsevier, pp. 2392.

7. Cabral R, Aragão J, Asano R, Neto J. (2008) Lesões no Joelho em Atletas de Handebol:Estudo em Atletas Universitários Participantes nos Jogos Universitários Brasileiros. Revista Treinamento Desportivo, 24-28.
8. Barsottini D, Guimarães AE, Morais PRd (2006) Relação entre técnicas e lesões em praticantes de judô. Revista Brasileira de Medicina do Esporte 12(1): 56-60.

9. Requa R, Garrick J (1996) Epidemiology of sports injuries. In: Caine D, Caine C, Lindner K, editors. Adult Recreational fitness. Champaign, Human Kinetics, p. 14-28.

10. Carvalho M, Pinheiro V, Pinto A, Nascimento M, Oliveira J, Fonseca F (2016) Lesão Desportiva em jovens judocas de alto nível competitivo. Revista de Medicina Desportiva Informa 7(3): 23-26.

11. Horta L (2011) As Lesões Típicas do Jovem Desportista. In: Horta L editor. Prevenção de Lesões no Desporto. 2a Edição, Texto Editores, p. $333-42$.

12. Cruz F (2011) Prevenção de Lesões no Judo. In: Horta L, editor. Prevenção de Lesões no Desporto. $2^{\text {a }}$ Edição, Texto Editores, pp. 397-406.

13. Carazzato JG, Cabrita H, Castropil W (1996) Repercussão no aparelho locomotor da prática do judô de alto nível: estudo epidemiológico. Rev Bras Ortop 31(12): 957-968.

14. Petrolito G, Fabiani M, Spinato R, Manconi R (1993) [Traumatic auricular hematoma in athletes: histopathological findings and clinical considerations on the experimental animal model]. Acta Otorhinolaryngol Ital 13(4): 339-347.

15. Raschka C, Parzeller M, Banzer W (1999) 15 years insurance statistics of incidents and accident types of combat sports injuries of the RhinelandPfalz Federal Sports Club]. Sportverletz Sportschaden. 13(1):17-21.

16. Medeiros D, Silva F (2008) Estudo da Prevalência de Lesões no Aparelho Locomotor em Praticantes de Judô. Belém: Universidade da Amazônia.

17. Clarsen B, Bahr R, Heymans MW, Engedahl M, Midtsundstad G, et al. (2015) The prevalence and impact of overuse injuries in five Norwegian sports: Application of a new surveillance method. Scand J Med Sci Sports 25(3): 323-330

18. Bahr R (2009) No injuries, but plenty of pain? On the methodology for recording overuse symptoms in sports. Br J Sports Med 43(13): 966-972.

19. Kim KS, Park KJ, Lee J, Kang BY (2015) Injuries in national Olympic level judo athletes: an epidemiological study. Br J Sports Med 49(17): 11441150

20. Cruz F. (1997) Lesões Traumáticas no Judo. Rev Port Med Desp.

21. Lima A, Nogueira J, Rocha V, Knackfuss M. (2000) Lesões em Judocas Incidência entre Escolares. Kinesis. 103-115.

22. Kujala UM, Taimela S, Antti-Poika I, Orava S, Tuominen R, et al. (1995) Acute injuries in soccer, ice hockey, volleyball, basketball, judo, and karate: analysis of national registry data. BMJ 311(7018): 1465-1468.

23. Sundgot-Borgen I, Garthe I (2011) Elite athletes in aesthetic and Olympic weight-class sports and the challenge of body weight and body compositions. J Sports Sci 29(Suppl 1): S101-114.

24. Nattiv A, Loucks AB, Manore MM, Sanborn CF, Sundgot-Borgen J, Warren MP, et al. (2007) American College of Sports Medicine position stand. The female athlete triad. Med Sci Sports Exerc. 39(10): 1867-1882.

25. Pocecco E, Ruedl G, Stankovic N, Sterkowicz S, Del Vecchio FB, et al. (2013) Injuries in judo: a systematic literature review including suggestions for prevention. Br J Sports Med 47(18): 1139-1143.

26. Franchini E, Brito CJ, Artioli GG (2012) Weight loss in combat sports: physiological, psychological and performance effects. J Int Soc Sports Nutr 9(1): 52 .

27. Artioli GG, Gualano B, Franchini E, Scagliusi FB, Takesian M, Fuchs M, et al. (2010) Prevalence, magnitude, and methods of rapid weight loss among judo competitors. Med Sci Sports Exerc. 42(3):436-42. 
28. Koral J, Dosseville F (2009) Combination of gradual and rapid weight loss: effects on physical performance and psychological state of elite judo athletes. J Sports Sci 27(2): 115-120.

29. Garthe I, Raastad T, Refsnes PE, Koivisto A, Sundgot-Borgen J (2011) Effect of two different weight-loss rates on body composition and strength and power-related performance in elite athletes. Int J Sport Nutr Exerc Metab 21(2): 97-104.

30. Garthe I, Raastad T, Sundgot-Borgen J (2011) Long-term effect of weight loss on body composition and performance in elite athletes. Int J Sport Nutr Exerc Metab 21(5): 426-435.

31. James G, Peter W (2003) Injury rates in adult elite judoka. Biol Sport 20(1): 25-32.

32. Crichton J, Jones DR, Funk L (2012) Mechanisms of traumatic shoulder injury in elite rugby players. Br J Sports Med 46(7): 538-542.

33. Chillemi C, Franceschini V, Dei Giudici L, Alibardi A, Salate Santone F, et al. (2013) Epidemiology of isolated acromioclavicular joint dislocation. Emerg Med Int 2013: 171609.

34. Longo UG, Huijsmans PE, Maffulli N, Denaro V, De Beer JF. (2011) Video analysis of the mechanisms of shoulder dislocation in four elite rugby players. J Orthop Sci 16(4): 389-397.

35. Pieter W, De Crée C (1997) Competition injuries in young and adult judo athletes. The Second Annual Congress of the European College of Sports
Science, Copenhagen, Denmark, Aug 20-23.

36. Pieter W. (2005) Martial arts injuries. Med Sport Sci 48: 59-73.

37. Pérez-Turpín J, Penichet-Tomás A, Suárez-Llorca C, Jose Antonio Carbonell-Martinez (2013) Injury incidence in judokas at the Spanish National University Championship Arch Budo: 9(3):211-218.

38. Carazzato J, Campos L, Carazzato S (1992) Incidência de lesões traumáticas em atletas competitivos de dez tipos de modalidades esportivas - trabalho individual de duas décadas de especialista em Medicina Esportiva. Rev Bras Ortop pp. 745-758.

39. Yard EE, Knox CL, Smith GA, Comstock RD (2007) Pediatric martial arts injuries presenting to Emergency Departments, United States 19902003. J Sci Med Sport 10(4): 219-26.

40. Del Vecchio F, Gonçalves A (2012) Descriptive epidemioloy of sports injuries. Rev Bras Med 69: 323-327.

41. Yamamoto T, Kigawa A, Xu T (1993) Effectiveness of functional ankle taping for judo athletes: a comparison between judo bandaging and taping. Br J Sports Med 27(2): 110-112.
This work is licensed under Creative Commons Attribution 4.0 License

To Submit Your Article Click Here:

Submit Article

DOI: $10.32474 /$ OSMOAJ.2018.01.000101

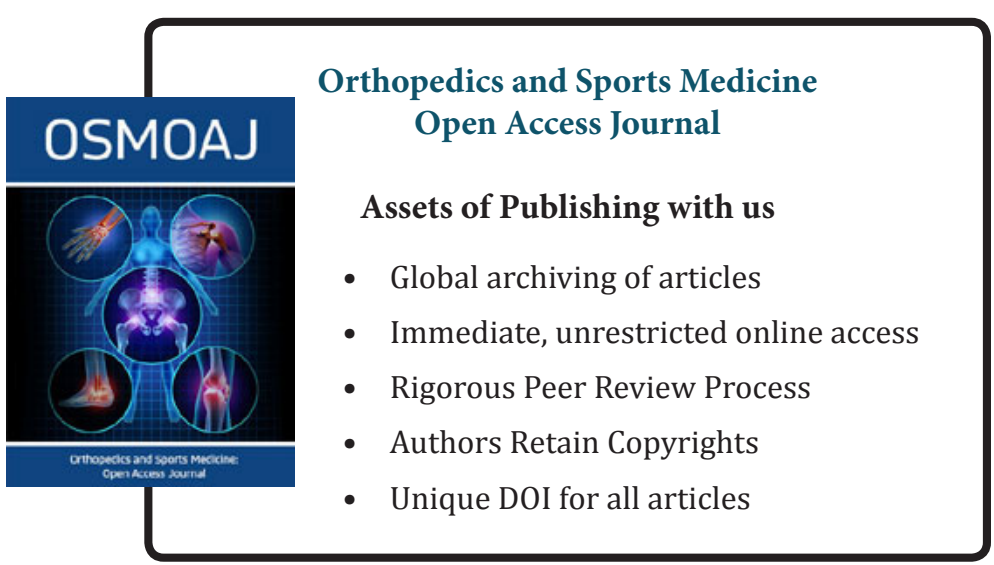

